\title{
Investor Sentiment and Firm Financial Performance of Malaysian IPO Firms: Pre and Post Financial Crisis
}

\author{
Zalina Zainudin ${ }^{1}$, Zarina Mohd Zaki ${ }^{2}$, Abdul Razak Abdul Hadi ${ }^{1}$, Hafezali Iqbal Hussain ${ }^{3}$ \& Mazhar Hallak \\ Kantakji \\ ${ }^{1}$ University Kuala Lumpur Business School, Malaysia \\ ${ }^{2}$ BAE Systems Applied Intelligence, Malaysia \\ ${ }^{3}$ Taylor's University, Business School, Malaysia \\ Correspondience: Zalina Zainudin, University Kuala Lumpur Business School, Malaysia.
}

Received: April 30, 2019

Accepted: May 30, 2019

Online Published: June 11, 2019

doi:10.5430/ijfr.v10n5p450

URL: https://doi.org/10.5430/ijfr.v10n5p450

\begin{abstract}
The main purpose of this study is to investigate an important issue in behavioural finance area that is the role of investor sentiment in determining firm performance, alongside with market timing and other fundamental firm factors in the context of Malaysian market. The impact of pre and post financial crisis during study period of 2004 to 2015 is incorporated in the analysis. The study uses a balanced panel data of 143 IPO firms in Malaysia during the study period. The sentiment index is developed using panel data cross section based on three IPOs proxies, which are IPO volume, market turnover and dividend premium. The findings indicate that market timing is found to have a strong influence towards firm performance with a positive and high level of significance relationship during pre and post financial crisis. Whereas investor sentiment does influence firm performance, particularly when timing is proxied by initial return before the financial crisis period. Other firm specific factors, growth show very strong positive relationship with firm performance. The remaining factors, namely tangibility of asset, profitability, size and industry show mix results either consistent or inconsistent with past literature irrespective of pre or post financial crisis. The finding offers a useful reference for firm managers' to consistently time the market for the new and subsequent issue. While the investors have to pay attention on important information available in the market than become overly optimistic about future prospect of any investment as firm will continue to exploit timing strategy in their financing decision.
\end{abstract}

Keywords: investor sentiment, market timing, financial performance, Initial Public Offering (IPOs), Malaysia

\section{Introduction}

On the average, $25 \%$ of the firms that came through Initial Public Offerings (IPO) decide to reissue new stocks using Seasoned Equity Offerings (SEO) within two years (Welch 1989). A major portion of the studies on new issue market concentrated either on short and long-run over and under-performance of the IPOs, or the literature that were narrowed down to western markets while placing performance of the seasoned equity offerings separately from the initial public offerings (Loughran \& Ritter, 2004; Loughran et al. 2004).

Given the significance of the long-run under and over-performance of the IPOs, quality of the company (Welch, 1989; Ibrahim and Ali, 2014; Sarwar and Mubarik, 2014; Okoye, 2014; Wilson, et.al. 2014; Chidoko, 2014; Ekpung, 2014; Kasasbeh, et.al. 2018; Hawamdeh, 2018; Yu-Chi and Lin, 2018), as well as limited cash flow hypothesis with respect to capital requirement for paying dividend in the presence of asymmetric information (Miller \& Rock, 1985), were among the studies that explain subsequent equity issuance. To a greater extent, the intention to raise new capital within a very short period of the IPO lends explanation to significant impact, either positive (Masulis, 1983; Fitriandi., Kakinaka \& Kotani, 2014; Aremu \& Ediagbonya, 2018) or negative (Myers \& Majluf, 1984), on the stock price of the issuing company. Issuance of new capital and its connection to stock price movement divert attention of the researchers to deeper investigations either into the factors affecting the performance of these issues or to understand the reasons behind sudden movement in market demand of these issues. Market timing and related theories basing on the behavioural finance predict that managers time the market while issuing new stocks or for the purpose other than announcements that includes merger and acquisitions and seasoned equity offerings (Baker \& 
Wurgler, 2002; Lamont \& Stein, 2005). This indicates also that an optimistic (or pessimistic) market may lead to benefits that are of paramount importance to issuing firms (Lowry, 2003), which has been characterised as investor sentiment in many studies. In addition, volume of trade increases during a high sentiment period (Daniel, Hirshleifer \& Subrahmanyam, 2008; Okafor and Shaibu, 2016; Mokuolu, 2018; Khemili and Belloumi, 2018; Zhang, 2018; Okon and Monday, 2017; Edeme, 2018; Almeqdadi, 2018; Setiyawati, et.al. 2018).

Studies on Malaysian stock market found investor sentiment as significant determinants of stock return. According to Abul \& Rumi (1999) and Abd Rahim, Nor \& Harjito (2006) the overall Malaysian capital market is to co-integrate with other markets and there is some sort of contagion effect among the markets. Overall, these studies indicate a sentiment driven expectation and trading behaviour in Malaysian market. Recent study by Fauzias et al. (2013) reported strong short-run as well as long-run relationships between investor sentiment index and three indicators namely stock price, bank deposit and currency value of financial performance. However, investor sentiment has similar or larger impact on equity issuance activities as it is in the case of stock prices. Moreover, it has been argued that the impact of investor sentiment would be stronger in emerging economies compared to their developed counterparts (Baker et al. 2010; Nepali,2018). This situation sets the motivation for this study, to investigate further on the role of investor sentiment with respect to the IPO firm performance. In order to investigate the role played by investor sentiment, this study develop a sentiment index using IPO volume (number of IPO issued), market turnover (firm share turnover) and dividend premium as a proxy for investor sentiment. To be more rigour, this study also includes market timing element in the analysis using three forms of proxy and also considered the impact of financial crisis during study period of 2004 to 2015 in order to verify pre and post influence on firm performance as it provides more meaningful analysis and overview from the financial crisis. Like other Asian countries, Malaysia suffered capital flights since the second quarter of 2008. There was a big drop in funds flowing into Malaysia with net financial and capital flows falling from negative MYR37.7 billion in 2007 to negative MYR118.5 billion in 2008. There is a reversal of portfolio capital flows due to repatriation by foreign participants which had significantly affected the stock market; the Kuala Lumpur Composite Index (KLCI) fell from 1393 in January 2008 to 876 points in December 2008. As there is a strong correlation between changes in net portfolio of equity flows and stock prices in Malaysia (Goh \& Lim, 2010), hence, it is worth to assess the impact of financial crisis on this study.

\section{Literature Reviews}

Malaysian capital markets comprise of more than 900 firms across 60 economic sub-groups. In order to bring a balance between capital structure choices and to reduce the overall cost of issuance, capital structure decision has been a challenge and involves a risk-return trade-off (Baker \& Martin, 2011) especially for firms in an emerging economy like Malaysia. Studies on capital structure decision provide additional evidence in favour of risk-return trade off using debt financing, see example Zalina et. al. (2017a, 2017b), Titman et al. (2014), Oppenheimer (2000). Their empirical evidence supported that debt in a firm's capital structure is beneficial to equity investors as long as they are rewarded up to the point where the benefit of using debt is offset against potential bankruptcy costs. To a greater extent, the decision to raise new capital within a very short period of the IPO lends explanation to significant impact, either positive (Masulis, 1983) or negative (Myers \& Majluf, 1984), on the stock price of the issuing company. Past literature identify increase in investment, drop in profitability and market timing as the major determinants of corporate intention to reissue securities after IPO within very short duration.

Issuance of new capital and its connection to stock price movement divert attention of the researchers to deeper investigations either into the factors affecting the performance of these issues or to understand the reasons behind sudden movement in market demand of these issues. Market timing and related theories base on the behavioural finance predict that managers time the market while issuing new stocks or for the purpose other than announcements that includes merger and acquisitions and seasoned equity offerings (Baker \& Wurgler, 2002; Lamont \& Stein, 2005). This indicates also that an optimistic (or pessimistic) market may lead to benefits that are of paramount importance to issuing firms (Lowry, 2003; Sallam, 2018), which has been characterised as investor sentiment in many studies. Recent studies on Malaysian stock market found investor sentiment as significant determinants of stock return, see example Fauzias et al. (2013). In addition, volume of trade increases during a high sentiment period (Daniel, Hirshleifer, \& Subrahmanyam, 2008).

Investor sentiment is defined as the tendency to speculate (Barberis, Shleifer \& Vishny 1998) or as the optimistic or pessimistic expectations of investors in financial markets (Baker \& Wurgler 2007). Investor sentiment has recently crossed the border of western literature and its positive relationship to financial market performance, e.g. stock price, bank deposit and currency value has been examined (Fauzias et al. 2013). In their study, Fauzias et al. (2013) reported strong short-run as well as long-run relationships between investor sentiment index and three indicators 
namely stock price, bank deposit and currency value of financial performance. However, investor sentiment has similar or larger impact on equity issuance activities as it is in the case of stock prices. Moreover, it has been argued that the impact of investor sentiment would be stronger in emerging economies compared to their developed counterparts (Baker et al. 2010).

Investor sentiment is measured through the creation of an index popularly known as investor sentiment index. The index can be created using a number of variables through principle component analysis. Three major types of proxies were used to feed into the principle component analysis. Firstly, there are survey based proxies those considered consumer sentiment index and various other direct investor surveys to form the investor sentiment index (Qiu \& Welch 2006; Caifen, Hailun \& Rongrong 2018). However, the survey has started recently and many developing countries may not have such surveys. Secondly, there could be market specific trading data that can be used to represent optimism (or pessimism) of investors. These market trading data include turnover and market capitalisation, IPO underpricing information, dividend to price information, etc. In a recent study, Fauzias at al. (2013) employed palm oil market index and FTSE ASEAN global index as measures to local market price generation and movement of local market with respect to the regional market. These were taken as proxies for investor sentiment in Malaysia. Finally, there are mixtures of the proxies used in more recent studies. These proxies are also called mega measures and these include a combination of survey-based opinion data and trading-based market data. It is important noting that survey-based data largely cover the macro aspect of the sentiment whereas the trading based proxies cover the micro aspect of the sentiment (Ahmed, Umrani, Qureshi \& Sarmad, 2018; Ali \& Haseeb, 2019; Haseeb, Abidin, Hye, \& Hartani, 2018; Haseeb., 2019; Suryanto, Haseeb, \& Hartani, 2018).

Investor sentiment is a contrarian predictor of the stock market return (Baker \& Wurglar, 2006). In the state of higher sentiment, over market activity increased. As a result, average stock price index increases as well. The increase in market activity has been strongly connected with optimistic market expectations by the investors. For instance, when the future outcomes of financial investment are assumed to be positive, investors react positively and thus invest heavily. However, the assumptions of the future prospect may arise from simple understanding, misevaluation, peer effect, or a tendency to speculation. Researchers in behavioural finance however argue that most of these assumptions by retail investors are seldom supported by fundamentals (Callaway, 2017).

In regard to the above explanation, this study hypothesized that investors' sentiment do influence IPOs' firm performance with respect to the market demand for new capital.

\section{Data and Methodology}

This study uses a balanced panel data, comprises 143 IPO firms that exist within the study period of 2004 to 2015 . The data had been obtained from Bloomberg, Thompson Reuters' Worldscope, and Bursa Malaysia Library databases. The firms included in this study must meet the criteria that it had issued the equity through seasoned offers after the IPO offering and second, available data for dividend premium computation. The rationale for this criterion is to enable the calculation of dividend premium as a proxy to develop the investor sentiment index. In this study, the dividend premium is calculated based on Tangjitprom (2011). The data from 143 firms was tabulated and sorted to meet the criteria for each variable proxy. It subsequently went through data cleaning exercise for the purpose of identifying outliers before it was transformed into a readable version. Diagnostic test was also run in order to test for data normality prior to regression analysis. The estimation is being carried out using panel data static framework which serves for long term equilibrium relationship. All the seven hypotheses are investigated in a static framework where the Ordinary Least Square (OLS) with fixed effects are applied in the estimation.

\subsection{Models and Variables of the Study}

This study looks into firm performance as measured by market performance indicator, Tobins Q, as the benchmark. Factors that has been identified as having an indicative influenced on the IPO firm performance is investor sentiment. The impact from investor sentiment on market is measured by the newly developed Sentiment Index. In this study, investor sentiment represents the behavioural perspective of investor demand on equity in the stock market. Development of sentiment index using panel data crosses section as a proxy for investor sentiment. The sentiment index is developed based on three proxies, which are IPO volume, market turnover and dividend premium. These proxies following are the extant studies by Lowry (2003) and Baker \& Wuglar (2006; 2007). As a robustness check, this study also considers three proxies for market timing namely initial return, stock price performance and excess return. Initial return provides a view to investors that positive initial return will benefit them as they gain higher returns and followed by rising IPO volume (Ritter, 1991). Excess return calculates the firm's equity over the market return and is used to remove the effect of the general movement of the stock market of the estimate results. Other capital structure factors that potentially influence IPO firm performance are proxies of tangibility, growth and 
profitability, where it is controlled by Firm Size and Industry. Table 1 present the description for the variables used in the study.

One general model beings developed and for robustness purposes, three sub-equation models being extended to cater for three different timing proxies for the regression estimation. The main and sub-equation are as per below equation:

$$
\begin{aligned}
& \mathrm{FP}=\alpha+\beta_{1} \mathrm{TIMG}_{\mathrm{i}, \mathrm{t}}+\beta_{2} \mathrm{SENT}_{\mathrm{i}, \mathrm{t}}+\beta_{3} \mathrm{GROW}_{\mathrm{i}, \mathrm{t}}+\beta_{4} \mathrm{TANG}_{\mathrm{i}, \mathrm{t}}+\beta_{5} \mathrm{PROF}_{\mathrm{i}, \mathrm{t}}+\beta_{6} \mathrm{SIZE}_{\mathrm{i}, \mathrm{t}}+\beta_{7} \mathrm{IND}_{\mathrm{i}, \mathrm{t}}+\varepsilon_{\mathrm{i}, \mathrm{t}} \\
& \mathrm{FP}=\alpha+\beta_{1}(\mathrm{IR})_{\mathrm{i}, \mathrm{t}}+\beta_{2} \text { SENT }_{\mathrm{i}, \mathrm{t}}+\beta_{3} \text { Growth }_{\mathrm{i}, \mathrm{t}}+\beta_{4} \text { Tang }_{\mathrm{i}, \mathrm{t}}+\beta_{5}(\mathrm{ROA}) \mathrm{t}_{\mathrm{i}, \mathrm{t}}+\beta_{6} \text { SIZE }_{\mathrm{i}, \mathrm{t}}+\beta_{7} \text { IND }_{\mathrm{i}, \mathrm{t}}+\varepsilon_{\mathrm{i}, \mathrm{t}} \\
& \mathrm{FP}=\alpha+\beta_{1}(\mathrm{SPP})_{\mathrm{i}, \mathrm{t}}+\beta_{2} \mathrm{SENT}_{\mathrm{i}, \mathrm{t}}+\beta_{3} \text { Growth }_{\mathrm{i}, \mathrm{t}}+\beta_{4} \text { Tang }_{\mathrm{i}, \mathrm{t}}+\beta_{5}(\mathrm{ROA}) \mathrm{t}_{\mathrm{i}, \mathrm{t}}+\beta_{6} \text { SIZE }_{\mathrm{i}, \mathrm{t}}+\beta_{7} \text { IND }_{\mathrm{i}, \mathrm{t}}+\varepsilon_{\mathrm{i}, \mathrm{t}} \\
& \mathrm{FP}=\alpha+\beta_{1}(\mathrm{ER})_{\mathrm{i}, \mathrm{t}}+\beta_{2} \text { SENT }_{\mathrm{i}, \mathrm{t}}+\beta_{3} \text { Growth }_{\mathrm{i}, \mathrm{t}}+\beta_{4} \operatorname{Tang}_{\mathrm{i}, \mathrm{t}}+\beta_{5}(\mathrm{ROA}) \mathrm{t}_{\mathrm{i}, \mathrm{t}}+\beta_{6} \operatorname{SIZE}_{\mathrm{i}, \mathrm{t}}+\beta_{7} \text { IND }_{\mathrm{i}, \mathrm{t}}+\varepsilon_{\mathrm{i}, \mathrm{t}}
\end{aligned}
$$

Where,

FP = Firm Performance measured by Tobins-Q

$\mathrm{a}=$ the constant term

$\beta=$ the estimated coefficient or loading of the respective factor

TIMG $=$ timing variable that captures the market valuation of the firm

SENT $=$ investor sentiment index for cross-section of data

GROW = growth variable for demand for capital

$\mathrm{TANG}=$ variable for asset tangibility

$\mathrm{PROF}=$ variable for profitability

SIZE = company size measured by market value

IND = industry classification of the firm listed in Bursa Malaysia and,

$\mathrm{IR}=$ Initial return

$\mathrm{SPP}=$ Stock price performance

$\mathrm{ER}=$ Excess return

$\varepsilon=$ error term

Table 1. List of variables and description

\begin{tabular}{ll}
\hline Variables & Description \\
\hline Tobins-Q & TOBINs-Q $=\frac{\text { Market Value of Equity }+ \text { Book Value of Total Debt }}{\text { Book Value of Total Asset }}$ \\
\hline Profitability & ROA $=\frac{\text { Earnings before interest, taxes and depreciation }}{\text { Total Assets }}$ \\
\hline $\begin{array}{l}\text { Tangibility } \\
\text { Growth }\end{array}$ & GROW $=\frac{\text { Total assets }- \text { book equity }+ \text { market equity }}{\text { Total assets }}$ \\
\hline Size & Log of total sales \\
\hline Industry classification & $\begin{array}{l}\text { Bursa Malaysia industry clustering: plantation, manufacturing, industrial, } \\
\text { infrastructural, and consumer }\end{array}$ \\
\hline
\end{tabular}




\begin{tabular}{|c|c|}
\hline $\begin{array}{l}\text { Timing: } \\
\text { - } \quad \text { Initial Return } \\
\text { (IR) }\end{array}$ & $\begin{array}{l}\text { Initial return of the firm } \\
\qquad \mathrm{R}_{\mathrm{it}}=\frac{\mathrm{P}_{\mathrm{it}}-\mathrm{S}_{\mathrm{i} 0}}{\mathrm{~S}_{\mathrm{i} 0}}\end{array}$ \\
\hline $\begin{array}{l}\text { - Stock price performance } \\
\text { (SPP) }\end{array}$ & $\begin{array}{l}\text { First difference of the log of annual share prices } \\
\qquad \mathrm{R}=\ln _{\mathrm{Pt}}-\ln _{\mathrm{Pt}}-{ }_{1}\end{array}$ \\
\hline $\begin{array}{l}-\quad \text { Excess return } \\
(\mathrm{ER})\end{array}$ & $\begin{array}{l}\text { Stock returns minus market returns } \\
\qquad \mathrm{R}=\mathrm{R}_{\mathrm{it}}-\mathrm{R}_{\mathrm{mt}}\end{array}$ \\
\hline $\begin{array}{l}\text { Investor Sentiment: } \\
-\quad \quad \text { IPO volume }\end{array}$ & No of IPO issued \\
\hline Turnover & Firm share turnover \\
\hline - $\quad$ Dividend premium & $\begin{array}{l}\text { Difference of the natural logarithm of the average market-to-book ratio } \\
\text { between firms paying dividends and non-payers }\end{array}$ \\
\hline
\end{tabular}

\section{Empirical Result}

Table 2 below provides a summary of results of the relationships between the determinant and the explanatory variables with firm performance and time period effect. Apart from that, this study is also looking into the effect of financial crisis on firm performance. During the study period of 2004 to 2015, a financial crisis had occurred in 2007 in the West and spill over in 2008 to Asian countries, including Malaysia. It is to this particular financial crisis that study refers to. The timing period is marked as the pre and post financial crisis period and known as time period 1 (TP1) before financial crisis and time period 2 (TP2) post financial crisis in Equation 1.1, 1.2 and 1.3.

Investor sentiment has a positive relationship with firm performance at TP1 before financial crisis when timing is proxied by initial return. Its relationship with firm performance however is not significant at TP2 that is after financial crisis. Investor sentiment has no significant relationship with firm performance at TP1 before financial crisis and TP2 after financial crisis when timing is proxied by stock price performance and excess return. Result of the analysis consistent with the idea that during certain periods, investors are overly optimistic and are willing to pay more for firms than they are worth. The result also support Purmanandam \& Swaminathan (2001) finding that IPOs are more overvalued at the offer price earn especially high first day returns and low returns over the next five years.

Timing, which is proxied by initial return, has a positive significant relationship with firm performance before financial crisis at TP1 as well as after financial crisis at TP2. However before the time of financial crisis TP1, timing has no significant relationship with firm performance when it is being proxied by stock price performance and excess return and in positive significant relationship at TP2 after financial crisis. The finding consistent with Baker \& Wurgler (2002) that suggest firms successfully time the market, having IPOs near market peaks. It is well known that managers will usually attempt to time the market when making decision to issue securities in the market. The action will result in the market having to react or under-react to the equity announcement in order for the manager to perceive mis-valuation, while price is not going to be immediately corrected. Hence, this situation will set a perception to the investors of firm performance which indirectly view as good stock to buy due to increase in price.

Profitability however has shown a mix results where it has a negative relationship with firm performance before the crisis; which make sense as firm profit shall have an impact due to financial crisis. Post financial crisis profitability shows a positive relationship where it does indicates that firm performance is trying to recap and towards recovery post financial crisis.

Tangibility has a negative relationship with firm performance before and after financial crisis. Tangibility measures collateral level a firm can offer to its debtors in case of bankruptcy. As argued by Harris \& Raviv (1991) that firm will prefer to finance asset with debt and low information asymmetry makes equity issuance less costly. Hence the results support the hypothesis accordingly. When measured before financial crisis tangibility remains as in insignificant negative relationship with firm performance. However, it is having a significant negative relationship post crisis. It shows that post crisis firm may have to dissolve their asset to support recovery post crisis.

Growth shows a positive relationship with firm performance even before and after financing crisis. The finding consistent with Jensen (1986) that firm with more investment opportunities have less need on debt payment possibly 
maintain a low-risk debt through less current leverage and maintain high investment.

Equally important, both firm size and industry has a negative relationship with firm performance either before or after financial crisis. The negative relationship between firm size and performance is inconsistent with past literature that view larger firm perform better than smaller firm (Booth et al. 2001; Desoomsak et al. 2004; Ceylan \& Aslan 2018). The finding for industry classification support the notion that the performance of IPO firms in different industries varies widely (Ritter, 1991). Firms tend to underperform relative to their industries and the market (Ahmad Zaluki \& Lim, 2012; Sohrabi et al. 2013).

Table 2. Fixed effect estimation results for equation (1) sub-equation 1.1, 1.2 and 1.3 on the relationship between firm performances with the explanatory variables with time period (profitability proxied by ROA)

\begin{tabular}{|c|c|c|c|c|c|c|}
\hline \multirow{4}{*}{ Independent Variables } & \multicolumn{6}{|c|}{ Dependent Variables } \\
\hline & \multicolumn{6}{|c|}{ TOBINs-Q } \\
\hline & \multicolumn{2}{|c|}{ Eq 1.1} & \multicolumn{2}{|c|}{$\mathrm{Eq} 1.2$} & \multicolumn{2}{|c|}{ Eq 1.3} \\
\hline & TP1 & TP2 & TP1 & TP2 & TP1 & TP2 \\
\hline \multirow[t]{2}{*}{ IR } & 0.2320 & 0.2179 & - & - & - & - \\
\hline & $(10.2801)^{* * *}$ & $(12.0257)^{* * *}$ & & & & \\
\hline \multirow[t]{2}{*}{ SPP } & - & & 0.0601 & 0.0712 & - & - \\
\hline & & & $(1.5871)$ & $(3.4266)^{* * *}$ & & \\
\hline \multirow[t]{2}{*}{ ER } & - & - & - & - & 0.0084 & 0.0415 \\
\hline & & & & & $(1.2523)$ & $(3.6249)^{* * *}$ \\
\hline \multirow[t]{2}{*}{ SENT } & 0.0038 & 0.0009 & 0.00115 & 0.0021 & 0.0024 & 0.0025 \\
\hline & $(2.0183)^{* *}$ & $(0.4070)$ & $(0.3850)$ & -0.8561 & $(1.1865)$ & $(1.1051)$ \\
\hline \multirow[t]{2}{*}{ ROA } & -0.0813 & 0.0875 & -0.0561 & 0.2796 & -0.0872 & 0.2650 \\
\hline & $(-0.4157)$ & $(0.8385)$ & $(-0.2071)$ & $(2.3993)^{* *}$ & $(-0.4217)$ & $(2.3692)^{* * *}$ \\
\hline \multirow[t]{2}{*}{ TANG } & -0.0023 & -0.0075 & -0.0212 & -0.0133 & -0.0139 & -0.0126 \\
\hline & $(-0.3069)$ & $(-1.1281)$ & $(-2.0582)^{* *}$ & $(-1.7178)^{*}$ & $(-1.7203)^{* *}$ & $(-1.7781)^{* *}$ \\
\hline \multirow[t]{2}{*}{ GROW } & 0.7700 & 0.5167 & 0.8395 & 0.5984 & 0.8831 & 0.5991 \\
\hline & $(26.7785)^{* * *}$ & $(27.3968)^{* * *}$ & $(22.9834)^{* * *}$ & $(28.8078)^{* * *}$ & $(30.4211)^{* * *}$ & $(31.5846)^{* * *}$ \\
\hline \multirow[t]{2}{*}{ SIZE } & -0.0127 & -0.0854 & -0.0199 & -0.0946 & -0.0184 & -0.0843 \\
\hline & $(-0.4199)$ & $(-4.4209)^{* * *}$ & $(-0.5475)$ & $(-4.3137)^{* * *}$ & $(-0.577)$ & $(-4.0877)^{* * * *}$ \\
\hline \multirow[t]{2}{*}{ IND } & -0.0436 & -0.0707 & -0.0326 & -0.0565 & -0.0389 & -0.0587 \\
\hline & $(-1.4106)$ & $(-3.191)^{* *}$ & $(-0.8484)$ & $(-2.2068)^{* *}$ & $(-1.18723)$ & $(-2.5005)^{* *}$ \\
\hline No of observations & 1430 & & 1430 & & 1430 & \\
\hline Adjusted $\mathrm{R}^{2}$ & 0.8713 & & 0.8404 & & 0.8529 & \\
\hline Durbin Watson & 1.6318 & & 1.6521 & & 1.5845 & \\
\hline F-statistics & $(62.2374)^{* * *}$ & & $(43.8638)^{* * * *}$ & & $(53.4576) * * * *$ & \\
\hline
\end{tabular}

Notes: Estimation result for Equation (1.1), (1.2) and (1.3). All regressions are estimated using Fixed Effect. The numbers in parenthesis are t-statistics calculated based on robust standard errors.

$* * *, * *, *$ indicate significance at $1 \%, 5 \%$ and $10 \%$ respectively.

\section{Conclusion}

The primary conclusion to be drawn from this study is that the findings support the notion of investor sentiment and timing theory is a valid phenomenon in emerging market of Malaysia.

This study provides evidence of relationship and influence of investor's sentiment on IPO firm performance. It was found that investor sentiment does influence firm performance, particularly when timing is proxied by initial return before the financial crisis period. The results shows that there is a psychological bases of investor sentiment following Barber \& Odean (2001) and Daniel et al. (2001) where investors become overly optimistic about future prospect of any asset they buy and do not bother about other factors influencing their decisions. The result also shows that firms successfully time the market, having IPOs near market peaks. This is consistent with market timing evidence found in Hovakimian et al. (2004) and Baker \& Wurgler (2002) where managers are found to time the market when there is high stock returns as the probability of equity issuance are increased. Results show that managers can consistently time the market which implicates that new issues always mispriced. While investors have to take this lesson as a learning point that firm will continue to exploit timing strategy in their financing decision. 


\section{References}

Abdul-Rahim, R., Nor, A. H. S. M., \& Harijito, D. A. (2006). Stock market linkagesin the ASEAN-5 region and implications on seasonality effect. Capital Markets Review, 14(1\&2), 65-80.

Abul, M. M., \& Rumi, M. (1999). Are Asian stock market fluctuations deu mainly to intra-regional contagion effects? Evidence based on Asian emerging stock market. Pacific Basin Finance Journal, 7(3-4), 251-282. https://doi.org/10.1016/S0927-538X(99)00013-X

Adesegun, O., \& Ayenakin, O. (2015). Insecurity and Foreign Direct Investment in Nigeria. International Journal of Sustainable Development \& World Policy, 4(4), 56-68. https://doi.org/10.18488/journal.26/2015.4.4/26.4.56.68

Ahmad Zaluki, N., \& Lim, B. K. (2012). The investment performance of MESDAQ market initial public offerings (IPOs). Journal of Accounting and Finance, 8(1),1-23.

Ahmed, U., Umrani, W. A., Qureshi, M. A., \& Samad, A. (2018). Examining the links between teachers support, academic efficacy, academic resilience, and student engagement in Bahrain. International Journal of Advanced and Applied Sciences, 5(9), 39-46. https://doi.org/10.21833/ijaas.2018.09.008

Ali, A., \& Haseeb, M. (2019). Radio frequency identification (RFID) technology as a strategic tool towards higher performance of supply chain operations in textile and apparel industry of Malaysia. Uncertain Supply Chain Management, 7(2), 215-226. https://doi.org/10.5267/j.uscm.2018.10.004

Almeqdadi, F. (2018). The Effects of Using an Interactive Software (GSP) on UAE Students' Attitudes towards Geometry. American Journal of Social Sciences and Humanities, 3(1), 22-28. https://doi.org/10.20448/801.31.22.28

Aremu, J. O., \& Ediagbonya, M. (2018). Trade and Religion in British-Benin Relations, 1553-1897. Global Journal of Social Sciences Studies, 4(2), 78-90. https://doi.org/10.20448/807.4.2.78.90

Baker, H. K., \& Martin, G. S. (2011). Capital structure and corporate financing decisions: theory, evidence and practice. John Wiley \& Sons. https://doi.org/10.1002/9781118266250

Baker, M. P., Wurgler, J. A., \& Yuan, Y. (2010). Global, local, and contagious investor sentiment. Journal of Financial Economics, 104, 272-287. https://doi.org/10.1016/j.jfineco.2011.11.002

Baker, M., \& Wurgler, J. (2002). Market timing and capital structure. The Journal of Finance, 57(1),1-32. https://doi.org/10.1111/1540-6261.00414

Baker, M., \& Wurgler, J. (2006). Investor sentiment and the cross-section of stock returns. The Journal of Finance, 61(4), 1645-1680. https://doi.org/10.1111/j.1540-6261.2006.00885.x

Baker, M., \& Wurgler, J. (2007). Investor Sentiment in the stock market. Journal of Economic Perspectives, 21(2), 129-151. https://doi.org/10.1257/jep.21.2.129

Barber, B. M., \& Odean, T. (2001). The internet and the investor. Journal of Economics Perpectives, 15(1), 41-54. https://doi.org/10.1257/jep.15.1.41

Barberis, N., Shleifer, A., \& Vishny, R. (1998). A model of investor sentiment. Journal of Financial Economics, 49(3), 307-343. https://doi.org/10.1016/S0304-405X(98)00027-0

Booth, L., Aivazian, V., Demirguc-Kunt, A., \& Maksimovic, V. (2001). Capital structures in developing countries. Journal of Finance, 56(1), 87-130. https://doi.org/10.1111/0022-1082.00320

Caifen, W., Hailun, F., \& Rongrong, C. (2018). The Research on Graduate Students' Understanding of Three Basic Limit Concepts. American Journal of Education and Learning, 3(2), 100-107. https://doi.org/10.20448/804.3.2.100.107

Callaway, S. K. (2017). How the Principles of the Sharing Economy Can Improve Organizational Performance of the US Public School System. International Journal of Public Policy and Administration Research, 4(1), 1-11. https://doi.org/10.18488/journal.74.2017.41.1.11

Ceylan, M., \& Aslan, D. (2018). Cardinal Number Acquisition of Turkish Children. Journal of Education and e-Learning Research, 5(4), 217-224. https://doi.org/10.20448/journal.509.2018.54.217.224

Chidoko, C. (2014). Labor and Economic Growth in Zimbabwe. The Economics and Finance Letters, 1(4), $24-29$. https://doi.org/10.18488/journal.29/2014.1.4/29.4.24.29

Daniel, K., Hirshleifer, D., \& Subrahmanyam, A. (2001). Overconfidence, arbitrage and equilibrium asset pricing. 
Journal of Finance, 56(3), 921-965. https://doi.org/10.1111/0022-1082.00350

Daniel, K., Hirshleifer, D., \& Subrahmanyam, A. (2008). Investor psychology and security market under- and overreactions. The Journal of Finance, 53(6), 1839-1885. https://doi.org/10.1111/0022-1082.00077

Desoomsak, R., Paudyal, K., \& Pescetto, G. (2004). The determinants of capital structure: Evidence from the asia pacific region, The Journal of Multinational Financial Management, 14, 387-405.

Edeme, R. K. (2018). Revisiting the Economic Growth-Welfare Linkages: Empirical Evidence from Nigeria. Asian Themes in Social Sciences Research, 1(1), 28-33. https://doi.org/10.33094/journal.139.2018.11.28.33

Ekpung, E. G. (2014). Public infrastructure spending and economic growth in Nigeria: An Error Correction Mechanism (ECM) approach. Journal of Social Economics Research, 1(7), 129-140.

Fauzias, M. N., Izani, I., \& Rashid, M. (2013). Exposure to investor sentiment in Malaysia: Services versus manufacturing stocks. Global Business \& Economics Anthology, (1), 239-248.

Fitriandi, P., Kakinaka, M., \& Kotani, K. (2014). Foreign direct investment and infrastructure development in Indonesia: Evidence from province level data. Asian Journal of Empirical Research, 4(1), 79-94.

Goh, S. K., \& Lim, M.-H. (2010). The impact of the global financial crisis: The case of Malaysia. Third World Network publication.

Harris, M., \& Raviv, A. (1991). The theory of capital structure. Journal of Finance, 46(1), 297-355.

Haseeb, M., Abidin, I. S. Z., Hye, Q. M. A., \& Hartani, N. H. (2018). The Impact of Renewable Energy on Economic Well-Being of Malaysia: Fresh Evidence from Auto Regressive Distributed Lag Bound Testing Approach. International Journal of Energy Economics and Policy, 9(1), 269-275.

Haseeb., H., Zandi. G., Hartani., N. H., Pahi., M. H., \& Nadeem., H. (2019). Environmental Analysis of the Effect of Population Growth Rate on Supply Chain Performance and Economic Growth of Indonesia. Ekoloji, 28(107).

Hawamdeh, G. (2018). Countering the Crimes of Administrative Corruption in the International Law. International Journal of Asian Social Science, 8(9), 751-769. https://doi.org/10.18488/journal.1.2018.89.751.769

Hovakimian, A., Hovakimian, G., \& Tehranian, H. (2004). Determinant of target capital structure: The case of dual debt and equity issues. Journal of Financial Economics, 71, 517-540. https://doi.org/10.1016/S0304-405X(03)00181-8

Ibrahim, P., \& Ali, M. (2014). Foreign Direct Investment Affluences in Iskandar Malaysia. International Journal of Management and Sustainability, 3(2), 72-83.

Jensen, M. (1986). Agency costs of free cash flow, corporate finance and takeovers. The American Economic Review, 76(2), 323-329.

Kasasbeh, H. A., Mdanat, M. F., \& Khasawneh, R. (2018). Corruption and FDI Inflows: Evidence from a Small Developing Economy. Asian Economic and Financial Review, 8(8), 1075-1085.

Khemili, H., \& Belloumi, M. (2018). Cointegration Relationship between Growth, Inequality and Poverty In Tunisia. International Journal of Applied Economics, Finance and Accounting, 2(1), 8-18.

Lamont, O. A., \& Stein, J. C. (2005). Investor Sentiment and Corporate Finance: Micro and Macro. The American Economic Review, 96(2), 147-151. https://doi.org/10.1257/000282806777212143

Loughran, T., \& Ritter, J. (2004). Why has IPO underpricing changed over time?. Financial Management, Autumn, 5-37.

Loughran, T., Ritter, J., Clayton, M. J., \& Qian, Y. (2004). Financial management wealth gains from tracking stocks: Long-Run performance and ex-date returns. Financial Management, 33.

Lowry, M. (2003). Why does IPO volume fluctuate so much?. Journal of Financial Economics, 67(2003), 3-40. https://doi.org/10.1016/S0304-405X(02)00230-1

Masulis, R. W. (1983). The impact of capital structure change on firm value: Some estimates. The Journal of Finance, 38(1), 107-126. https://doi.org/10.1111/j.1540-6261.1983.tb03629.x

Miller, M. H., \& Rock, K. (1985). Dividend policy under asymmetric information. The Journal of Finance, 40(4), 1031-1051. https://doi.org/10.1111/j.1540-6261.1985.tb02362.x

Mokuolu, J. O. (2018). Assessment of the Development and Growth of Nigerian Economy as a Function of FDI 
Flows. Journal of Accounting, Business and Finance Research, 2(2), 91-97.

Myers, S. C., \& Majluf, N. S. (1984). Corporate financing and investment decisions when firms have information that investors do not have. Journal of Financial Economics, 13(2),187-221. https://doi.org/10.1016/0304-405X(84)90023-0

Nepali, S. R. (2018). Income diversification and bank risk-return trade-off on the Nepalese commercial banks. Asian Economic and Financial Review, 8(2), 279-293. https://doi.org/10.18488/journal.aefr.2018.82.279.293

Okafor, C., \& Shaibu, I. (2016). Modelling Economic Growth Function in Nigeria: An ARDL Approach. Asian Journal of Economics and Empirical Research, 3(1), 84-93. https://doi.org/10.20448/journal.501/2016.3.1/501.1.84.93

Okon, E. O., \& Monday, O. I. (2017). Empirical and Evidence-Based Investigation: External Debt, Poverty and Economic Growth Nexus. International Journal of Applied Economics, Finance and Accounting, 1(1), 37-47.

Okoye, J. C. (2014). Anti-corruption crusade in Nigeria: More words than deeds. International Journal of Public Policy and Administration Research, 1(2), 47-63.

Oppenheimer, P. H. (2000). An Investigation of current debt levels of equity REITs. Journal of Real estate Portfolio Management, 6(3), 225-237.

Purnanandam, A., \& Swaminathan, B. (2004). Are IPOs really underpriced. The Review of Financial Studies, 17(3), 811-848. https://doi.org/10.1093/rfs/hhg055

Qiu, L. X., \& Welch, I. (2006). Investor sentiment measures. Working Paper, Brown University and NBER.

Ritter, J. R. (1991). The long-run performance of initial public offerings. The Journal of Finance, 46(1), 3-27.

Sallam, S. (2018). Productivity and Technical Efficiency in Islamic Banks: Cross-Country Analysis. Asian Journal of Economic Modelling, 6(1), 1-7. https://doi.org/10.18488/journal.8.2018.61.1.7

Sarwar, N., \& Mubarik, M. S. (2014). Foreign Direct Investment (FDI) and Employment: A Case of Province of Punjab, Pakistan. The Economics and Finance Letters, 1(4), 59-65.

Setiyawati, H., Iskandar, D., \& Basar, Y. S. (2018). The Quality of Financial Reporting through Increasing the Competence of Internal Accountants and Accrual Basis. International Journal of Economics, Business and Management Studies, 5(1), 31-40. https://doi.org/10.20448/802.51.31.39

Sohrabi, M., Biglar, R., \& Jamshidian, M. M. (2013). The relationship between IPOs and long- term industry performance: Evidence from Tehran stock exchange. Management Science Letters, 3, 2759-2766. https://doi.org/10.5267/j.msl.2013.10.002

Suryanto, T., Haseeb, M., \& Hartani, N. H. (2018). The Correlates of Developing Green Supply Chain Management Practices: Firms Level Analysis in Malaysia. International Journal of Supply Chain Management, 7(5), 316.

Tangjitprom, N. (2011). Dividend premiums and dividend payment decisions in Thailand. $2^{\text {nd }}$ International Conference on Economics, Business and Management (p. 22).

Titman, S., Twite, G., \& Sun, L. (2014). REIT and commercial real estate returns: A post mortem of the financial crisis. Real Estate Economics, (512).

Welch, I. (1989). Seasoned offerings, imitation costs, and the underpricing of initial public offerings. The Journal of Finance, 44(2), 421-449. https://doi.org/10.1111/j.1540-6261.1989.tb05064.x

Wilson, A., David, U., Mary, O., \& Beatrice, E. (2014). How Telecommunication Development Aids Economic Growth: Evidence from Itu Ict Development Index (IDI) Top Five Countries for African Region. International Journal of Business, Economics and Management, 1(2), 16-28.

Yu-Chi, S., \& Lin, H. P. (2018). Causality Relationship between Tourism, Foreign Direct Investment and Economic Growth in Taiwan. Asian Journal of Economic Modelling, 6(3), 287-293.

Zalina, Z., Izani, I., Hafezali, I. H., \& Razak, A. H. (2017b). Debt and financial performance of REITs in Malaysia: An optimal debt threshold analysis. Jurnal Ekonomi Malaysia, 51(2), 73-85.

Zalina, Z., Izani, I., Rasidah, M. S., \& Hafezali, I. H. (2017a). Debt and financial performance of reits in malaysia: A moderating effect of financial flexibility. Jurnal Pengurusan, 50, 3-12.

Zhang, W. B. (2018). Endogenous Economic Growth with Education Subsidies. International Journal of Emerging Trends in Social Sciences, 2(1), 10-16. https://doi.org/10.20448/2001.21.10.16 